\title{
IMMIGRATION IN ITS RELATION TO PAUPERISM
}

\author{
By Kate Holladay Claghorn \\ Tenement House Department, New York City
}

While it is plain enough that foreign immigration has some connection with the problem of pauperism since common observation and all the statistics available unite in showing that the majority of the recipients of our charity, public and private, are of foreign birth, it is equally certain on the other hand that pauperism is not something that the immigrant brings with him, but is the result of a considerable period of life and experiences here.

In 1903 , even with the careful scrutiny now given by the immigration department, out of 857,000 foreign immigrants only 5,812 , or less than seven-tenths of one per cent.,were deported as likely to become public charges, and only 547 persons, or less than one-tenth of one per cent. of the immigration of the previous year, were returned within one year after landing as having become such.

In age distribution the immigrant group is the diametric opposite of the pauper group; the former consisting mainly of young adults, a group at the height of working power and ability for selfhelp; the latter of children and the old. This of itself indicates that much pauperism among the newly arrived is unlikely.

Furthermore, as a matter of fact, it takes some time for the immigrant to find his way to the poorhouse. The census of 1890 showed that 92 per cent. of the foreign-born male almshouse paupers had been in this country ten years or more, and their average length of residence here was probably much higher.

It is, in short, the immigration of past decades that is filling our poorhouses to-day. Of the foreign-born almshouse paupers enumerated in 1890,83 per cent. were Irish, Germans and Englishour older immigrants-while Italians, Austrians and Russians, the newer arrivals, were hardly to be found in almshouses at all. And this preponderance of the older immigrants in the almshouses was not merely due to their preponderance in the general population at that time. The ratio of paupers to the million of the same nation- 
ality in the population at large was also far higher for the older than for the newer immigrants, being 2,163 for the English, 2,436 for the Germans, and 7,550, just three-fourths of one-per cent., for the Irish; while for the Italians it was only $8 \mathrm{I} 7$, for the Austrians, 779, and for the Russians, 586.

In view of the present uneasiness with regard to the changed racial character of immigration, and its great and increasing volume, it is of importance to learn, as far as possible, whether the newer Italians, Austrians and Russians will follow their Irish, English and German predecessors to the poorhouse in about the same proportion, or whether there are other elements at work to make the situation more or less favorable.

Taking the new immigrants by races, rather than by nationalities, the bulk of them are included in three groups-Italian, Slavic and Hebrew-which, together, now make up about two-thirds of our immigration year by year.

Assuming that the immigration for last year may be taken as typical, the following table indicates some of the group-characteristics which are significant with regard to probable pauperism:

\begin{tabular}{|c|c|c|c|c|c|c|c|c|}
\hline \multirow[b]{2}{*}{$\begin{array}{l}\text { Immigration for the Year End } \\
\text { ing June } 30,190.3 \text {. }\end{array}$} & \multirow{2}{*}{ 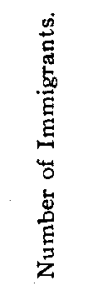 } & \multirow{2}{*}{ 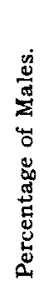 } & \multicolumn{3}{|c|}{$\begin{array}{c}\text { Percentage of Males } \\
\text { who are }\end{array}$} & \multirow{2}{*}{ 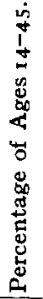 } & \multirow{2}{*}{ 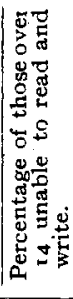 } & \multirow{2}{*}{ 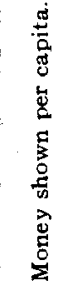 } \\
\hline & & & 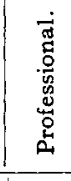 & 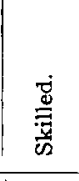 & 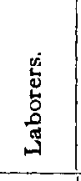 & & & \\
\hline $\begin{array}{l}\text { Italians } \ldots \ldots \ldots \ldots \ldots \ldots \ldots \ldots \\
\text { Hebrews } \\
\text { Slavs and Magyars: }\end{array}$ & $\begin{array}{r}233,546 \\
76,203\end{array}$ & $\begin{array}{l}81 \\
58\end{array}$ & $\begin{array}{r}.4 \mathrm{I} \\
1.13\end{array}$ & $\begin{array}{l}\text { I5.00 } \\
54.00\end{array}$ & $\begin{array}{l}74.00 \\
16.00\end{array}$ & $\begin{array}{l}84 \\
70\end{array}$ & $\begin{array}{l}43 \\
26\end{array}$ & $\begin{array}{r}\$ 12.93 \\
9.70\end{array}$ \\
\hline 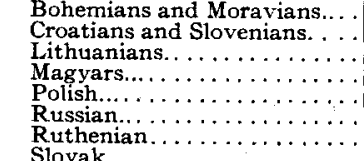 & $\begin{array}{r}9,591 \\
32,907 \\
14,432 \\
27,124 \\
82,343 \\
3,608 \\
9,843\end{array}$ & $\begin{array}{l}61 \\
89 \\
75 \\
75 \\
72 \\
80 \\
78\end{array}$ & $\begin{array}{r}1.43 \\
.12 \\
.06 \\
.42 \\
.08 \\
2.28 \\
.08 \\
.06\end{array}$ & $\begin{array}{r}44.50 \\
5.65 \\
5.33 \\
9.88 \\
6.10 \\
16.80 \\
2.10\end{array}$ & $\begin{array}{l}32.00 \\
93.00 \\
89.00 \\
83.00 \\
85.00 \\
69.00 \\
96.00 \\
88\end{array}$ & $\begin{array}{l}75 \\
93 \\
90 \\
89 \\
88 \\
85 \\
92 \\
8\end{array}$ & $\begin{array}{l}1 \frac{1}{2} \\
35 \\
41 \\
10 \\
30 \\
31 \\
50\end{array}$ & $\begin{array}{r}22.67 \\
12.37 \\
9.05 \\
12.59 \\
9.54 \\
25.06 \\
9.40\end{array}$ \\
\hline 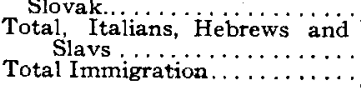 & $\begin{array}{r}34,427 \\
524,024 \\
857,046\end{array}$ & 71 & .06 & 5.60 & 88.00 & 87 & 21 & I 2.00 \\
\hline
\end{tabular}

The Italians, it is seen, make up the largest single group, and in 1903 exceeded in number any single race group for any preceding year, with the sole exception of the Germans in 1882 . 
This group is peculiarly favorable as regards pauperism in respect to age and sex composition, with the highest percentage of males of any of the groups except the Croatians, and a high percentage of persons between fourteen and forty-five. But they are also the most illiterate of any of the groups but one-the Ruthenian-and the money shown is only $\$ 2.93$ per capita.

It must be kept in mind, however, with regard to the poverty of immigrants as indicated in the immigration reports, that, for all classes of immigrants, the amount of money shown is probably far short of the money brought, as the immigrant from motives of caution will naturally exhibit only so much as he thinks necessary to gain him admittance.

The 74 per cent. of males classed as "laborers" were mainly farm laborers, from the country districts. The 15 per cent. skilled workers were, for the most part, from the towns, and were mainly barbers, carpenters, masons, shoemakers and tailors. The few "professionals" were musicians, sculptors and painters, and teachers.

The typical Italian immigrant, then, is the illiterate, unskilled laborer, with no capital but his sturdy arms and legs, and the poverty, illiteracy and lack of skill that characterize him are the qualities so often adduced in present-day discussion to show that our newcoming immigrants are on "the brink of pauperism." If so, a "brink" must be wider than is generally supposed-it takes the Italian, at least, so long to get over it.

The Italian immigrant comes here not only because of economic pressure at home, but because of a definite economic demand on this side for unskilled labor. In particular, the construction companies, now busily engaged in providing every city and town in the country with subways, trolley lines, power houses, mills, factories and skyscrapers, are absorbing this class of labor so freely that the Italian unskilled laborer, upon arrival, is quickly picked up and placed, and we hear nothing of him in relation to poverty or pauperism for some time.

A part of this good result must be, in fairness, ascribed to the padrone system, which, with all the evils it involves, at least makes the connection of laborer with employer much more rapid and certain than it could be without some such system.

An important factor in keeping the Italian laborer off the 
hands of charity in his early period of residence is the great mobility of the newly-arrived Italian immigration. Up to the present time no statistics of departures have been kept, but it has been generally known that at the close of the busy season for unskilled work, or in a year of industrial depression, the return current to Italy is strong. In the past year it has been calculated that the number of east-bound steerage passengers was from 28 to 30 per cent. of the number of west-bound steerage passengers. The percentage for Italians alone would have been much higher than that, as they are by far the most mobile of any of the race groups in our immigration.

This very mobility is often regarded as an especial danger of Italian immigration; it should rather be regarded as a safety valve, or rather as a self-acting "law of settlement" which returns to their native communities those who are in danger of pauperism here, but who are able, in the home country, owing to the lower scale of prices and living, to maintain themselves until they are needed on this side again.

After a few years, however, the Italian immigrant saves up enough to bring his wife and children to this country, or to marry here, and then we begin to find him as a dependent.

As the Italian population is found mainly in the large cities62 per cent. of them living in the 100 principal cities in 1900the conditions among the Italian poor in New York City may be taken as fairly typical. Accordingly, to learn something about the emergence of dependence among the Italians, a study of Italian cases in the records of the New York Charity Organization Society for five city blocks, chosen for the density of their Italian population, was made. For the cases studied, the average period of residence in the United States for the head of the family was eight years and three months at the time of the first application for relief. In three-fourths of the cases the head of the family had been in the country five years or more. Only 6 per cent. had been in the United States less than one year. As to occupation, the male heads of families in the cases studied were about equally divided between the skilled and unskilled trades, in contrast to the proportion of one skilled to five unskilled in immigration; and about 5 per cent. of the applicants for relief were of the professional class, again in 
contrast to the less than one per cent. of that class among Italian immigrants in general.

It is to be noted, furthermore, that these "professional" cases got into difficulties, not only in greater proportion, but in a much shorter time than the skilled and unskilled workers. In contrast to the eight years average residence shown for all cases taken together, the greater number of the professional cases were forced to apply for relief within a few months of arrival.

These followers of the professions were teachers, lawyers and musicians, and were, apparently, among the hardest to care for. One case, of a teacher, may be taken as typical of the fate of the educated, but poor, Italian in this country.

This man, a widower, with several children married, and in professional circles in Italy, came to this country with his two youngest sons, boys of twelve and fifteen. Unable to find employment in his own line, he undertook to support himself and one of the boys by rolling cigars. As he knew nothing about the trade, he was obliged to confine himself to the cheapest grades of the product, and, working night and day in his little tenement room, was able to roll, rather badly, about 200 cigars a day, for which his net earnings were forty cents. When he was at last obliged to apply for relief, he had been in the country only four months.

A prominent Italian who was applied to in relation to this case, stated that "as a rule, the educated Italian does not amount to much in this country."

In three-fifths of the cases studied, applicants for relief had relatives here, so that the placing of burdens upon those who are of blood kindred, which is one of the first principles of organized relief, could be, and, as a matter of fact was, applied in a considerable proportion of instances.

In somewhat less than half of the cases where there was a male head of the family, the wife followed some occupation, usually "sweat-shop" work-such as finishing coats, "pants" or skirts, or making artificial flowers. Where there was no male head the mother of the family was, naturally, more often found with an occupation.

In many of the families the older children were employed, but not so frequently as might, perhaps, have been expected. Less 
than one-quarter of the cases studied showed employment of children. The boys occupied were in factory work of some kind, or were bootblacks or newsboys-none were in outdoor, unskilled labor. The girls were in factories, or did sewing at home, like their mothers.

In cases where family relations were unbroken, the causes of need were mainly sickness and lack of work. The typical case may be pictured something like this: The man of the family, with his wife's aid, has been earning just enough to live on, and lay up a little something besides. A period of unemployment, or an illness, has drawn upon the little hoard until it is exhausted, and then appeals are made for food, for coal, or for payment of rent. In a large proportion of these cases, after a brief period of relief-giving, the head of the family finds work, or the sickness comes to an end, and the family is on its feet again.

An encouraging feature of the situation is that few cases were shown where the cause of need was shiftlessness or laziness, or the "beggar spirit," and almost none in which drunkenness appeared as a factor.

The moral causes of Italian dependence are of another kind. Many of the cases studied were of families broken up by the desertion of husband or wife, by the separation of husband and wife, or by the imprisonment of the husband for some offense or other, leaving his wife and children a burden on the public. Many of these cases of desertion seemed to be due to sheer inability of husband and wife to get along peaceably together. In one of the cases where the family was in distress owing to the imprisonment of the husband, the offense for which he was sent up was that of choking his wife in a fit of anger. In other cases, the man cannot endure his , wife, or his wife's relatives, and simply vanishes, to find peace in his own way. In still other cases, a man with a wife in Italy takes another in this country, and, on the appearance of wife number one on these shores, finds it convenient to disappear, leaving both wives and sets of children upon public care.

This easy throwing off of family ties is attributed by Italians largely to the influence of the new country upon the immigrant. At home, the church does not permit divorce, and holds the man fast to his marital duties: on this side, the grasp of the church is loosened, and, for the immigrant, there is no organized body of 
social opinion to take its place in restraining him from taking advantage of what he conceives to be the privileges of a "land of liberty."

A feature of Italian dependence, usually regarded as especially characteristic, is the large number of commitments of children asked for. This has been taken to indicate in the Italian lack of parental affection, and the presence of the pauper spirit.

In justice to them, however, it should be said that in the cases studied, three-fourths of the instances where commitment of children was asked, were in families which were already broken up, because of desertion, or for the more creditable reason of death of husband or wife. And it should also be said that Italian parents are in general unwilling to part with their children permanently, or to have them placed out in distant homes, but want them near at hand, where they can be visited, and want them to return home as soon as they are able to help maintain themselves.

The Slavic group cannot, like the Italian, be considered as a whole. Reference to the table given above shows that the group includes a number of sub-groups, of more or less widely differing characteristics, from the Bohemians and Moravians, with their low percentage of males, and persons between fourteen and fifteen, and high proportion of literacy and money per capita, to the Ruthenians, Lithuanians and Croatians, with their high degree of illiteracy and poverty, and large proportion of adult male unskilled laborers.

These people, however, are alike in one respect, and also like the Italians-the high proportion shown of unskilled laborers or peasant farm laborers from country districts. There are few representatives of the cities among them.

Their destinations, too, are as diverse as their kinds. Some of the sub-groups mass themselves in special regions of two or three States, others scatter widely; some are found in the cities, others in the country, or in small towns. It is, then, impossible, without a study of each people in each center of aggregation, to give a comprehensive or detailed account of their conditions as to pauperism. The most that can be done in the present space is to show briefly some of the salient features of the main groups.

Taking the immigration report of 1903 as some indication of their destination it is seen that all of the various Slavonic groups 
go in large proportion to Illinois and Pennsylvania, to work in the mines and mills of both States. Many of those who go to Illinois, however, find their way to Chicago, where they enter the sweatshop industries characteristic of foreign life in our large cities. Many Croatians and Slovenians go to Minnesota and Missouri, to the mines; a considerable number of Lithuanians were found headed for Massachusetts, and of Slovaks to New Jersey. Ohio also claims a considerable proportion of several of the groups, for manufactures and farm labor.

None of the sub-groups, however, is so generally scattered as the Poles, by far the largest of them numerically, who are found en route to nearly all of the States, to become, with equal readiness, coal miners in Pennsylvania, steel workers in Illinois, farm laborers in Connecticut and Massachusetts, and, in surprising numbers, farm owners in these same States, where they are bringing back to productiveness the farms abandoned by native-born owners in the mad rush for the cities and the more fertile West.

Of these various classes and kinds, the city groups, engaged in sweat-shop work, suffer the effects of the sharp competition in that line of occupation, and fall into temporary distress from which they have to be helped out.

The farm laborers apparently have no difficulty in making their way, and there is practically no occasion for charitable aid toward them. It is from their ranks that the farm owners are recruited, and the fact that it is comparatively easy to pass from one class to the other seems to show that the Slavic farm laborer's condition is in general a good one.

The Slavic mine and mill workers are still another class-to general thinking the typical Slavic immigration, whose coming is felt as a danger. The situation of these workers is peculiar in many ways. Take the anthracite coal miners as an instance. To three Pennsylvania counties one-tenth of the entire Slavic immigration into the United States is called, whether by the general expectation of employment, or, as is claimed by some, directly by the employers, who want to keep on hand more men than they can employ continuously, in order to lower the rate of wages, and break the power of the unions. In this restricted district, with thousands of new recruits pouring in every year, with labor disputes constantly arising, with 
ups and downs in the market for the product of the mines, there are long periods of unemployment for a considerable proportion of the miners.

It is not surprising to learn, then, that in the three anthracite counties the number per thousand of the population receiving outdoor relief is about three times the general average for the State.

This is by no means, however, due entirely to direct economic pressure. Some of the excess is due to what may be counted as an incident of the industry, and in that sense an economic causethe accidents characteristic of coal mining, which leave women and children to be cared for by the public.

Another factor is the intemperance so conspicuously absent in the Italian. The Slav miner is a hard and ferocious drinker, and this habit must inevitably have its effect on the rate of pauperism.

There does not seem to be, however, much distress due to desertion. In general the mine workers ${ }^{I}$ are said to work hard for the maintenance of their offspring, and are anxious to clothe and feed them well.

Finally, it is interesting to note, as a suggestion with regard to pauperism generally, that one careful observer of the situation attributes a great part of this high rate of pauperism to political influence in the giving of charity. Roberts shows the present rates of persons relieved for Coal Township to be 22.8 to the Iooo, while for Schuylkill County it is only 7.3 to the 1000 , and says further: "Three years ago the latter had about the same proportion as the former, but in the last few years the Taxpayers' Association of Schuylkill County took the list of outdoor relief in hand and thoroughly purged it of its abuses, and, without working injury to the worthy poor, succeeded in reducing the number 50 per cent., and the expenditures were cut down from $\$ 40,000$ to $\$ 25,000$." 2

The remaining class of our newer immigrants, the Hebrews, differ in certain important respects from both the Slavs and the Italians. The bulk of immigration of this people is inconsiderable-less than one-third the number of Italians in 1903 , and only about nine per cent. of the total immigration; but they come almost entirely by

\footnotetext{
- Roberts, Anthracite Coal Communities, p. 300
}

2 Roberts, Anthracite Coal Communities, p. 142. 
reason of economic and social pressure at home; without any special economic demand on this side for their services, and they settle in an abnormally high proportion in two or three of our largest cities. Reference to the table shows a comparatively small proportion of males, but a high percentage of persons between the ages of 14 and 45. A small proportion of old people makes early pauperism unlikely, as only five and one-half per cent. were forty-five and over. The percentage of illiteracy is not high, and is less important even than the figures would show, as the illiterate are mainly women, whose lack of education would have no significance in the economic struggle, but the amount of money shown was only $\$ 9.70$ per capita. Again it should be remembered, however, that not all the money brought is shown, and the Jews, being an especially cautious people, would be less likely than the Italians to show all they had.

The Italians and Slavs come mainly from country districts; the Jews, owing to the peculiar conditions fixed for them in their own countries, largely from cities. Another contrast is found in the range of occupations; the Hebrews showing over one per cent. of the males belonging to the professional class, and fifty per cent. to the skilled class, while only fifteen per cent. were classed as laborers. The skilled workers were mainly clerks, carpenters, painters and glaziers, shoemakers and tailors. The last class, the tailors, was the most numerous, making up about two-fifths of the male skilled workers, and twenty-one per cent. of all male arrivals. Five per cent. of the male arrivals were classed. as "merchants," meaning small traders, peddlers, etc.

The typical Jewish immigrant, then, is of the small trading and artisan class of the towns, and finds his natural habitat in the cities on this side. As there is no crying demand here for the work the Jewish immigrant can' do, the labor market in these lines being already well stocked, he is obliged to pick up whatever he can, and usually finds his way into the sweat shop, or starts out as a peddler, in competition with thousands of others, as poor and as eager for work as himself.

Owing to this great economic pressure, it would naturally be expected that the Jewish immigrant should have recourse to charity sooner than some other classes of immigrants. The report of the United Hebrew Charities of New York for Igor showed that forty 
per cent. of the new applicants for relief in that year had been in the country less than one year. It is encouraging to find, however, that this early recourse to relief does not mean an early retreat to the almshouse, or, apparently, the beginning of a permanent burden on private charity. It was stated in an article on Jewish Charities, published in the ANNals of THE ACADEMY in May, 1903, that, out of a Jewish population in Greater New York approximating 600;000, there were only 17 Jewish paupers on Blackwell's Island. As to private charity the same writer states that, of rooo applicants for relief at the United Hebrew Charities in October, 1894, 602 had not applied for assistance after December, 1894 , and of the remainder, only 67 families were dependent in any way on the Society in January, 1899. In other words, over ninety-three per cent. of the cases had become independently self-supporting.

According to the Report of the United Hebrew Charities for I9OI, the main causes of need appear to be sickness and lack of work, as with the Italians. These two causes run into each other, indeed. When work is not plentiful proper provision cannot be made for sickness, while sickness, on the other hand, exhausts not only savings, but vitality, besides throwing the worker out of employment, so that securing employment subsequently is more difficult. More than half of the cases were distinctly of this nature, while a considerable proportion of the remainder involved these causes.

In these cases, as well as among the Italians, there seems to be a general absence of moral causes of need, and, perhaps, to an even greater degree, a conspicuous absence of drunkenness as a cause, or of thriftlessness and shiftlessness.

Among the Jews, as among the Italians, we find a considerable proportion of cases of deserted wives, and requests for commitment of children. But here the cause seems rather another variety of the purely economic cause. Family affection and loyalty are so strong among the Jews that when the Jewish husband leaves his family, or the Jewish parent of either sex asks commitment of children, it is usually through sheer inability to earn the bread necessary to fill all the mouths.

The general conclusions to be drawn with regard to the newer elements in immigration, as a whole, seem to be, first, that among them the unskilled worker gets along better than the skilled, and 
the illiterate than the literate. This is not to say that skill and education are in themselves a handicap in the industrial contest, or that all racial groups with a large proportion of illiterate, unskilled labor get along better than all those with a high degree of literacy and a larger proportion of skilled labor.

The industrial success of any group in this country depends upon its adjustment to conditions of demand here, and some of the race groups seem able to find suitable openings for skill and education.

But on the whole there is more chance for the newcomer into any social aggregation to find foothold if he is willing to begin at the bottom, and in this country in particular there is less demand for skilled labor from outside, owing to the fact that the present inhabitants are willing to follow those lines of work themselves, but are unwilling to occupy themselves in unskilled labor. On the other hand, the skill, and especially the education of the newer European immigrant, have been directed along lines that do not suit American conditions. In the evolutionary phrasing, undifferentiated social elements can more easily adapt themselves, by specializing, to fit a new environment, than can the elements which have been already differentiated to fit a former environment.

Any restriction of immigration, then, that is based on an educational qualification, would be meaningless with respect to the growth of pauperism. Such a qualification would, among the newer immigrants at least, let in the class which, though small, is the most difficult to provide for, and would keep out the class that can best provide for itself.

The next conclusion to be drawn with regard to the newer immigration is that it relieves us in large proportion of that part of pauperism due to drunkenness, as the Italians and Hebrews, who make up three-fifths of the number, are temperate people.

The following table not only shows the importance of the drink habit as an accompaniment of pauperism, but also confirms the conclusions already arrived at as to the respective tendencies of the different race elements in this regard: 


\begin{tabular}{|c|c|c|c|}
\hline \multirow{2}{*}{ Proportion of cases due to drink for } & \multirow{2}{*}{$\begin{array}{l}\text { Percentage of } \\
7,225 \mathrm{C} . \mathrm{O} . \mathrm{S} . \\
\text { cases }(8) .\end{array}$} & \multicolumn{2}{|c|}{$\begin{array}{c}\text { Percentage due to intemperate } \\
\text { habits of some member } \\
\text { of family. }\end{array}$} \\
\hline & & $\begin{array}{l}29,823 \text { C. O. S. } \\
\text { cases }(0)\end{array}$ & $\begin{array}{l}8,420 \text { almshouse } \\
\text { paupers }(7)\end{array}$ \\
\hline 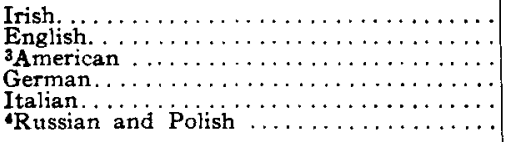 & $\begin{array}{r}23.62 \\
16.93 \\
15.14 \\
7.83 \\
5.60 \\
3.24\end{array}$ & $\begin{array}{r}37.84 \\
25.07 \\
23.89 \\
20.16 \\
3.42 \\
6.73\end{array}$ & $\begin{array}{r}44 \cdot 55 \\
40.75 \\
34 \cdot 95 \\
27.88 \\
9.09 \\
12.96\end{array}$ \\
\hline
\end{tabular}

Again, the causes of need among the newer immigrants appear to be more largely economic than moral. The following table shows statistically how far this conclusion is justified, and how the newer immigrants compare with the older immigrants :

\begin{tabular}{|c|c|c|c|c|c|c|}
\hline $\begin{array}{l}\text { Proportion of } 7,225 \text { C. O. S. cases } \\
\text { due to various causes }(8) .\end{array}$ & Irish. & English. & $\begin{array}{l}\text { Ameri- } \\
\text { can. }\end{array}$ & German. & Italian. & $\begin{array}{l}\text { Russian- } \\
\text { Polish. }\end{array}$ \\
\hline \multirow{2}{*}{ 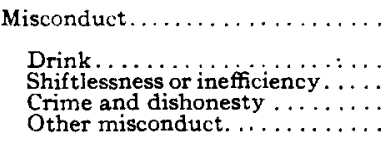 } & 31.63 & 29.25 & 27.99 & 16.95 & 18.67 & 11.62 \\
\hline & $\begin{array}{r}23.62 \\
5.78 \\
1.58 \\
.65\end{array}$ & $\begin{array}{r}16.93 \\
7.12 \\
2.36 \\
2.84\end{array}$ & $\begin{array}{r}15.14 \\
9.19 \\
1.40 \\
2.26\end{array}$ & $\begin{array}{r}7.83 \\
7.48 \\
.58 \\
. .06\end{array}$ & $\begin{array}{r}5.60 \\
8.41 \\
3.73 \\
.93\end{array}$ & $\begin{array}{r}3.24 \\
7.09 \\
1.29\end{array}$ \\
\hline \multirow{3}{*}{ 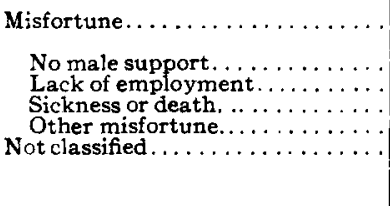 } & 66.26 & 68. I 5 & 68.84 & 79.28 & 78.51 & 85.13 \\
\hline & $\begin{array}{r}5.07 \\
18.87 \\
19.80 \\
22.52 \\
2.11 \\
\end{array}$ & $\begin{array}{r}3.16 \\
24.68 \\
22.94 \\
17 \cdot 37 \\
2.60\end{array}$ & $\begin{array}{r}4.11 \\
24 \cdot 57 \\
20.31 \\
19.85 \\
3.17\end{array}$ & $\begin{array}{r}4.27 \\
28.62 \\
22.92 \\
13.47 \\
3.77 \\
\end{array}$ & $\begin{array}{r}6.54 \\
30.85 \\
16.82 \\
24.30 \\
2.82\end{array}$ & $\begin{array}{l}6.45 \\
23.87 \\
25 \cdot 16 \\
29.65 \\
3 \cdot 25\end{array}$ \\
\hline & 100.00 & 100.00 & 100.00 & 100.00 & 100.00 & 100.00 \\
\hline
\end{tabular}

It may be of interest to see how the newer immigrants compare with the older as to deserting their wives and families. The following percentages ${ }^{9}$ of 8,028 charity cases show a fairly uniform rate, except for the Russians and Poles, which is more than double that of any of the others:

\footnotetext{
3 Includes native born of foreign parentage.

1 Includes Hebrews and Slavs.

(5) Warner: American Charities, p. 44.

(6) Koren: Economic Aspects of the Liquor Problem, pp. 76-7.

(7) Op. cit., pp. 1 I $^{-1} 5$.

(8) Compiled from Warner: American Charities. Table viii.

- Compiled from Warner, American Charities p. 53.
} 


\begin{tabular}{l|r|r|r|r|r|r}
\hline & Irish. & English. & American. & German. & Italian. & $\begin{array}{l}\text { Russian- } \\
\text { Polish. }\end{array}$ \\
\hline Married $\ldots \ldots \ldots \ldots \ldots \ldots \ldots \ldots$ & $\begin{array}{r}44.00 \\
6.00\end{array}$ & $\begin{array}{r}45.82 \\
7.78\end{array}$ & $\begin{array}{r}46.63 \\
7.00\end{array}$ & $\begin{array}{r}58.40 \\
5.53\end{array}$ & $\begin{array}{r}60.68 \\
\mathbf{5 . 9 8}\end{array}$ & $\begin{array}{r}\mathbf{6 2 . 5 0} \\
\mathbf{5} .34\end{array}$ \\
\hline
\end{tabular}

Worthy of note, besides, in the above figures, is the steadily increasing proportion of applicants for relief living in normal family relations, as we pass from the Irish, at the head of the older immigrants, at the left of the table, to the Russians and Poles closing the list of the newer immigrants at the right. This indicates the more occasional, temporary, or emergent nature of the need of the newer inmigrants, the true pauper being shaken loose to great degree from family ties.

The same thing is shown by the following percentages ${ }^{10}$ of numbers of persons in families asking aid in 4, 176 Boston and New York charity cases:

\begin{tabular}{|c|c|c|c|c|c|c|}
\hline & Irish. & English. & American. & German. & Italian. & $\begin{array}{l}\text { Russian- } \\
\text { Polish. }\end{array}$ \\
\hline $\begin{array}{l}\text { One to two in family } \ldots \ldots \ldots \ldots \\
\text { Three to five in family } \ldots \ldots \ldots \\
\text { Over five } \ldots \ldots \ldots \ldots \ldots \ldots \ldots\end{array}$ & $\begin{array}{l}34.96 \\
46.38 \\
18.62\end{array}$ & $\begin{array}{l}36.69 \\
49.19 \\
14.14\end{array}$ & $\begin{array}{l}35.71 \\
47.02 \\
17.27\end{array}$ & $\begin{array}{l}29.49 \\
50.49 \\
20.11\end{array}$ & $\begin{array}{l}18 \cdot 33 \\
51 \cdot 36 \\
30.26\end{array}$ & $\begin{array}{l}13 \cdot 27 \\
49 \cdot 99 \\
36.69\end{array}$ \\
\hline
\end{tabular}

It will be seen here that English, Americans and Irish lead in proportion of what may be called fragmentary families-one person, or husband and wife, deserting or deserted by their childrenand that the Italians and Russians lead in large families, while the proportion of medium-sized, but normal, families is very much the same for all of the groups.

In the above tables it is to be borne in mind that under the heading "Russians and Poles" the unlike race groups, Slavs and Hebrews, are united. We cannot, then, draw conclusions for these peoples separately, but only for the newer immigration as a whole.

The main source of danger as to pauperism from our immigrants of to-day is in the severe economic pressure they are subjected to. While the unskilled laborer finds immediate employment on arrival here, and is thus kept for the time being from the need of charity, it is at such a low wage that there is little margin for provision

10 Compiled from Warner, American Charities, pp. 50, 51 . 
against the accidents and enlarging needs of life-sickness, unemployment, increase of family cares, old age and death. Is this pressure actually so great that these needs cannot be met, and that our newer immigrants, after a period of ups and downs, during which they are helped along by temporary relief, must in large proportion find their way to the poorhouse at last?

There are two influences at work-the one beginning as the other slackens-to stave off this fate: in the early period of the new immigrant's life here, a phenomenal thrift that enables him to save money from a wage that seems hardly sufficient to sustain life; in the later period, a gradual raising of the standard of life that, without diminishing the determination to get on in the world, shifts the stress of effort from saving to earning.

As a result of these tendencies a rapidly growing prosperity is to be seen among these newer peoples.

The Italians are for the most part still in the saving stage, but their savings are surprisingly large. It has been estimated that the Italians in New York hold property to the amount of $\$ 60,000,000$ and over, a value which is, however, far below that of the Italian colonies of St. Louis, San Francisco, Boston and Chicago. ${ }^{11}$

The amount held by Italians in savings banks alone in New York is estimated at over $\$ 15,000, \infty 00$, and the savings sent home to Italy are sufficient in many cases to set whole villages on their financial feet again.

The Jews are under greater economic pressure than the Italians, but, on the other hand, they have a greater and more intense personal ambition, which is always pressing and pushing to lift them upwards. The increase of wealth on the East Side in New York is as noteworthy as the increase in poverty. A considerable proportion of the tenements of the city are owned, one or two in a holding, by Jewish immigrants, and the amount of savings laid away in the banks of the East Side is surprising.

Even the Slav miners of the anthracite region show a considerable financial surplus. In four towns of the mining region it has been estimated that the Slavs own $\$ 2,500,000$ in real estate; or about \$Ioo per capita of the Slav population in those towns. In one town they owned 39 per cent. of the homes, the values ranging from $\$ 350$

11 Giro C. Speranza; "Charities," May 7, r904, p. 462. 
to $\$ 7,000$, and averaging $\$ 953$. The payments on land are prompt. There is, in addition, much money sent home, and the banks are doing well by reason of Slavic custom.

Furthermore, the standard of life is undoubtedly rising among these people. They live in better houses than ten years ago, and in dress and other outward tokens are showing the effect of contact with people in a more advanced social stage.

While this process of economic improvement is going on, however, with the newer immigrants, there are other influences at work that make in the direction of pauperism. Overwork, poor food, and life in the airless, sunless and crowded tenements of the city, or in the equally crowded and even more unsanitary dwellings of the mill- or mining-town - the conditions accompanying the early stages of the immigrant's progress-tend strongly to break down the physical health of the sturdy Italian or Austrian peasants, or even of the Jews, more accustomed to the unsanitary conditions of city life. An alarming increase of tuberculosis among the Jews and Italians in our large cities, the phenomenally high death rate of Italian children in the same, and of Slavic children in the anthracite region, seem to show that the tendency is already a strong one.

As a secondary result of enfeebled health, and as a direct result of overcrowding, there is the further danger of moral as well as physical breakdown, both in the first and second generation, and an emergence of the causes of pauperism which have been so far notably absent-drunkenness, vice and idleness.

In our large cities the Italians and Hebrews are learning to patronize the saloons, and are being drawn into the meshes of organized vice. There is no reason to think, however, that this tendency will spread through the mass of either people. In the history of immigration so far the race groups that have shown general intemperance here have brought it with them as a race trait; those who were temperate on arrival have, in general, remained so.

The drink difficulty, so far as the newer immigrants is concerned, is not so great that it cannot be in great part checked by municipal forethought.

It is in insuring conditions favorable to physical health, however, that the municipality or other form of local government has the most important part to play. Keep the immigrant population 
in a fairly normal condition of health, and they will, of themselves, go far towards working out the rest of their salvation. And this can undoubtedly be done by intelligent municipal regulation, especially of housing conditions. The history of tenement house reform shows that the tenement house in itself has been responsible for much of the physical and moral degradation seen in our large cities. It is, indeed, impossible to calculate how great has been the social loss and waste, how heavy the additional burden of pauperism, due to the policy of allowing landlords to hive as many human beings as possible upon a given space of land, without regard to health or decency.

In country districts, also, housing conditions are of the utmost importance, although this has largely been overlooked in the great interest aroused in city conditions. In the anthracite region, for instance, a high disease rate and infant death rate among the Slavs, as well as some of the social and moral evils there prevalent, are certainly due in large part to the wretched general sanitation of the towns, to the relegation of the Slavs, as far as possible, to undesirable quarters in the towns, and to the "company houses"-the poorer ones at least-in which about sixteen per cent. of the miners are obliged to live.

Improvement in housing conditions has this special advantage as a means of social betterment, that its effects are relatively permanent. General sanitary laws as to cleanliness, disposal of refuse, etc., may be obeyed to-day and disregarded to-morrow; but if houses are once put up with adequate light and ventilation, if windows are once cut, court space provided for, sufficient distance from adjoining buildings secured, the height restricted, and proper plumbing installed-all this cannot be done away with in a day; and in fact, there is no great inducement to do away with it when the house owner has once made the investment.

There is, in short, no surer and more comprehensive means of raising the standard of life among the poor than by compulsory improvement of their dwellings. If rents in the crowded sections of cities are raised in the process, it is one inducement the more to the spread of population into more open, and cheaper, districts, thus relieving congestion in the older quarters.

Finally, there is a more or less remote danger of the emergence 
of pauperism in the second generation of our newer immigrants, due to physical and moral deterioration from causes already mentioned. It is impossible to tell, at the present time, how near, and how serious, this danger will prove to be. On the one hand, we see influences at work to reduce the physical health of children, to relax family discipline, and to disincline them for entering into any but a small range of pursuits.

It cannot be said that the effects of our public school training on the children of immigrants is altogether fortunate. The ideals held up by the public schools to-day are too exclusively academic. The practical result of their teaching seems to be to turn the desires of children as far as possible from manual labor, and inspire them all with the ambition to be teachers, clerks, stenographers, attendants in stores, or at least factory workers. The young Italian boy will rather loaf on a street corner than go into unskilled manual work; and where opportunities are as crowded as they are in the lines he wants to follow, the chances are that he, and many like him, will loaf a long time, and learn many vices that are likely to lead to pauperism.

Much the same may be said of the Slavic child. The only set of immigrants for whom our public schools appear to be comparatively well adapted are the Hebrews, who seem to be able by their means not only to strive for but to find places in commercial or professional pursuits. There are indications, however, that the schools are now beginning to recognize this lack, and, by provision for manual training, and training in the domestic and useful arts, are making a beginning toward raising hand work to the level of esteem accorded to other matters learned in school. It is certainly a serious defect in a system of popular education that it can reach persons in one great sphere of economic life only by taking them out of it.

On the whole there seems no reason why the second generation of Italian, Slavic and Hebrew immigrants, as a body, should furnish more paupers than did the Irish, Germans and English. The original stock of the newer immigration has been shown to be rather less, than more, inclined to pauperism than the older; the same influences now at work on the second generation of the newer immigrants were equally at work to drag down the children of older immigrants. 
While, however, the class of dependents of native birth and foreign parentage of the older immigration is in some respects more hopeless, and more troublesome to deal with than those of the first generation, the mass of it is small-so small that it has slight importance in statistics of pauperism.

Foreign pauperism, as a rule, ends with the first generation, and there is no reason to think that the newer immigrants will prove an exception. 